\title{
PENGARUH QUALITY ASSURANCE DAN ISO 9000 TERHADAP KINERJA PROGRAM STUDI (STUDI PADA SEBUAH PERGURUAN TINGGI SWASTA DI YOGYAKARTA)
}

\author{
Aftoni Sutanto \\ Universitas Ahmad Dahlan \\ e-mail: aftoni@uad.ac.id
}

\begin{abstract}
Higher education is very important for the community. The college is an institution that organizes the process of education or teaching, research and service to the community. This research was conducted at a private university in Yogyakarta. The purpose of this research was to examine the influence of Quality Assurance and ISO 9000 on performance. The population of this research is the entire department. The sampling technique using saturated or census sampling technique, i.e. by using all components of the population considered to be able to assess the implementation of the Quality Assurance (QA) and the implementation of ISO 9000. The respondents in this study is the Chairman or Secretary of department. Technique of data analysis in this study uses the program of Generalized Structured Component Analysis (GSCA) to perform analysis of hypothesis testing. The result show that the diversity of variable QA, ISO and performance can be explained by models research with having value as fit as much as 73,6\%. The remaining 26,4\% described by other variables. Variable $Q A$ influential not significantly to the performance of a course of study in college. Variable ISO 9000 influential not significantly to the performance of course of study. While variable QA influential positive and significantly to ISO 9000. On the contrary, variable ISO 9000 influential positive and significantly to $Q A$.
\end{abstract}

Keywords: department, ISO 9000, performance, quality assurance

\section{PENDAHULUAN}

Seiring dengan perkembangan zaman, maka tingkat pendidikan masyarakat mengalami peningkatan. Oleh sebab itu pendidikan pada tingkat perguruan tinggi dipandang sangat penting bagi masyarakat. Perguruan tinggi dengan produknya berupa jasa pendidikan merupakan lembaga yang berfungsi sebagai tempat untuk menyelenggarakan pendidikan atau pengajaran, penelitian dan pengabdian pada masyarakat (Singgih dan Rahmayanti, 2008). Sistem penjaminan mutu yang banyak diterapkan oleh Perguruan Tinggi (PT) di Indonesia menggunakan beberapa model sistem mutu yaitu sistem penjaminan mutu yang dikeluarkan oleh Kemdiknas, ISO 9001:2008, dan Malcolm Balridge National Quality Award (MBNQA). Beberapa PT di Indonesia sudah banyak yang menerapkan sistem penjaminan mutu dan bahkan menggabungkan sistem-sistem mutu tersebut dengan menerapkan ISO 9001:2008 
dengan IWA-2, dan MBNQA, disamping sistem penjaminan mutu Kemdiknas yang diakreditasi melalui Badan Akreditasi Nasional Perguruan Tinggi (BAN-PT). Sementara itu, beberapa PT lain menggunakan ISO 9001:2008 sebagai basis dari sistem penjaminan mutunya, disamping sistem penjaminan mutu Kemdiknas.

Namun demikian, masih banyak PT di Indonesia yang belum menerapkan sistem penjaminan mutu yang menyebabkan masih banyaknya program studi di Indonesia yang hanya berakreditasi $\mathrm{C}$ dan bahkan lebih dari $50 \%$ program studi yang belum terakreditasi ini disebabkan antara lain kurangnya sumber daya dan fasilitas, program studi masih baru, desain kurikulum yang lemah, bangunan yang tidak memenuhi syarat, lingkungan kerja buruk, sistem dan prosedur tidak sesuai, jadwal kerja yang tidak terencana, pengembangan staf yang tidak memadai, dan secara umum program studi itu memiliki manajemen kualitas yang lemah (Gasperz, 2011). Kondisi seperti ini menunjukkan bahwa secara nasional kinerja pendidikan tinggi di Indonesia masih rendah. Berdasarkan fenomena tersebut, perlu diupayakan peningkatan kinerja program studi.

Studi ini dilaksanakan di sebuah perguruan tinggi swasta di Yogyakarta, di mana untuk meningkatkan mutu atau kualitas perguruan tinggi dilakukan dengan menggunakan beberapa instrumen yang tepat, antara lain penjaminan mutu (Quality Assurance) dan International Standart Organization (ISO) 9000. Diharapkan setelah mengimplementasikan sistem penjaminan mutu dan ISO 9000 akan meningkatkan kualitas pendidikan sehingga dapat bersaing pada taraf nasional maupun internasional.

\section{REVIEW LITERATUR DAN HIPOTESIS}

\section{Quality Assurance (QA)}

Pendekatan QA adalah untuk mengejar kualitas (Collins, 1994 dikutip dalam Jabnoun,
2002). Tujuan dari QA adalah kesesuaian produk, layanan dan proses yang memenuhi persyaratan dan standar. Kesesuaian ini dicapai melalui pengukuran dan kontrol secara sistematis untuk mendeteksi penyebab khusus untuk mencapai proses standardisasi. QA merupakan perpanjangan dan meliputi dari kontrol kualitas (Jabnoun, 2002). QA merupakan perencanaan kualitas dan pencegahan cacat melalui sistem dan proses dokumentasi seluruh rantai pasokan (Garvin, 1998, dikutip dalam Jabnoun, 2002). Tanggung jawab mutu bersama dengan semua fungsi dengan maksud untuk "building-in" kualitas. Manajemen puncak juga memainkan peran utama dalam upaya untuk memastikan koordinasi yang tepat dan membangun sistem yang disesuaikan dengan semua persyaratan, bahan baku yang memadai, pelatihan yang tepat dan sistem penghargaan yang efektif.

QA biasanya mengacu pada semua tindakan terencana dan sistematik yang diperlukan untuk menyediakan cukup keyakinan bahwa suatu produk atau jasa akan memenuhi persyaratan yang ditentukan untuk kualitas. Proses QA secara umum melibatkan tidak hanya evaluasi produk tetapi juga evaluasi organisasi atau sistem yang memasok produk terhadap standar yang ditentukan dalam rangka membangun kemampuan untuk terus menghasilkan produk dengan standar yang ditetapkan. Jaminan kualitas (QA) mencakup semua kegiatan dan fungsi yang dibutuhkan untuk menyediakan produk atau jasa untuk memuaskan persyaratan yang diberikan kualitas. Ini pada dasarnya adalah fungsi preventif. Jaminan kualitas didasarkan pada prinsip bahwa pencegahan lebih baik dari pada mengobati dan lebih ekonomis untuk mendapatkan hal yang benar. Setiap orang harus bertujuan melakukan hal yang benar pertama kalinya dan setiap kali, sehingga mencapai zero defect dalam kinerja untuk melaksanakan jaminan mutu, tepat dan sistematis prosedur yang disusun dan diikuti oleh semua pihak. 
Menurut Yorke (1997), tujuan QA terhadap kualitas pendidikan tinggi adalah 1) membantu perbaikan dan peningkatan secara terus-menerus dan berkesinambungan melalui praktek yang terbaik dan mau mengadakan inovasi; 2) memudahkan mendapatkan bantuan, baik pinjaman uang atau fasilitas atau bantuan lain dari lembaga yang kuat dan dapat dipercaya; 3) menyediakan informasi pada masyarakat sesuai sasaran dan waktu secara konsisten, dan bila mungkin, membandingkan standar yang telah dicapai dengan standar pesaing; dan 4) menjamin tidak akan adanya hal-hal yang tidak dikehendaki.

\section{International Standart Organization (ISO) 9000}

Menurut Porter dan Tenner (1996) banyak organisasi memperkenalkan kualitas melalui upaya registrasi ISO 9000. Studi empiris oleh Anderson et al., (1999) mendukung pandangan ini. Anderson et al., (1999) menunjukkan bahwa adopsi ISO 9000 merupakan cara untuk mencapai keunggulan bersaing melalui manajemen kualitas. Douglas et al., (2003) mengakui bahwa sertifikasi ISO 9000 membawa perbaikan kualitas. ISO 9000 merupakan sistem kualitas yang tumbuh paling cepat di dunia. Meskipun popularitasnya luar biasa, terdapat banyak ketidakjelasan mengenai nilai bisnis dari sertifikasi ISO 9000. ISO 9000 menyangkut sistem kualitas dan konsistensi, yang bertujuan untuk memberi keyakinan pelanggan mengenai pemasoknya dengan memastikan bahwa pemasok memiliki proses manajemen yang memberikan konsistensi. Namun ISO 9000 itu sendiri tidak secara langsung menjamin kualitas produk.

Beberapa studi menemukan bahwa nilai bisnis utama dari sertifikasi ISO 9000 adalah membuka pintu bagi pasar yang sebelumnya tertutup (Brecka 1994). Peningkatan pangsa pasar dan produktivitas adalah alasan utama mengapa perusahaan memilih untuk registrasi ISO 9000.
Akan tetapi perusahaan memiliki ekspektasi rendah bahwa registrasi ISO 9000 sendiri akan mampu meningkatkan produktivitas dan pangsa pasar (Ebrahimpour et al., 1997). Sedangkan Terziovski et al., (1997) mengungkapkan bahwa manfaat yang terkait dengan sertifikasi ISO 9000 terutama adalah efisiensi prosedur dan tingkat kesalahan, namun kemungkinan lebih kecil untuk pangsa pasar. Yeung et al., (2003) menemukan bahwa efektivitas dari ISO 9000 tergantung pada pemahaman yang benar oleh manajemen senior dan sikap pada standar tersebut. Corbett et al. (2002) dan Mann dan Kehoe (1994) memperoleh bukti bahwa adopsi ISO 9000 memiliki dampak positif pada kinerja bisnis. Corbett et al. (2005) dan Chow-Chua et al. (2003) menyatakan bahwa sertifikasi ISO 9000 membawa perbaikan kinerja keuangan yang signifikan.

Persyaratan kualitas untuk registrasi ISO 9000 telah terdokumentasi dengan baik dalam literatur. Ebrahimpour et al. (1997) menemukan dalam surveinya bahwa audit kualitas internal, pengendalian dokumen, tindakan perbaikan, pelatihan, dan pengendalian rancangan memerlukan upaya paling tinggi untuk memperoleh registrasi ISO 9000. Ketika pertanyaan yang sama diajukan dalam survei ini, empat persyaratan pertama, beserta tiga persyaratan lain (catatan kualitas, sistem kualitas, dan pengendalian proses), dipandang sebagai beberapa elemen paling penting dalam proses registrasi ISO 9000. Tujuh elemen ini berhubungan erat dengan yang lain dalam satu faktor tunggal. Setiap elemen secara signifikan berhubungan dengan faktor yang mendasari. Jadi ketujuh elemen ini dipilih sebagai variabel terukur yang mewakili upaya registrasi ISO 9000.

\section{Kinerja Perguruan Tinggi}

Dalam dunia pendidikan tinggi, banyak indikator yang digunakan untuk mengukur kinerja program studi. Dalam penelitian ini, variabel yang digunakan untuk mengukur kinerja 
adalah jumlah peminat program studi dan kuota program studi.

Hipotesis dalam penelitian ini adalah:

H1 : Implementasi QA berpengaruh terhadap kinerja program studi.

$\mathrm{H} 2$ : Implementasi QA berpengaruh terhadap ISO 9000.

H3 : Implementasi ISO 9000 berpengaruh terhadap kinerja program studi.

H4 : Implementasi ISO 9000 berpengaruh terhadap QA

\section{METODE PENELITIAN}

Populasi dalam penelitian ini adalah seluruh program studi pada sebuah perguruan tinggi swasta di Yogyakarta yang berjumlah 34 program studi. Teknik sampling yang digunakan dalam penelitian ini adalah teknik sampling jenuh, yaitu teknik pengambilan sampel dengan menggunakan seluruh populasi yang dianggap mampu menilai penerapan Quality Assurance dan ISO 9000 terhadap kinerja program studi. Teknik pengumpulan data dalam penelitian ini dilakukan dengan menyebarkan kuesioner kepada responden yang telah ditetapkan. Instrumen survei menggunakan skala Likert lima poin di mana 1 menunjukkan paling rendah, 2 rendah, 3 rata-rata, 4, tinggi dan 5 menunjukkan paling tinggi. Responden dalam penelitian ini adalah ketua dan atau sekretaris program studi yang dianggap mampu menilai pengaruh Quality Assurance (QA) dan ISO 9000 terhadap kinerja program studi.

Uji validitas menggunakan korelasi product moment. Instrumen dikatakan valid dengan menggunakan kriteria nilai koefisien korelasi (r) $\geq 0,30$ (Solimun, 2010). Pengujian reliabilitas menggunakan Crobach's Coefficient Alpha dengan ukuran multi-item memiliki nilai alpha di atas 0,60 (Malhotra dalam Solimun, 2010). Teknik analisis data menggunakan Generalized Structured Component Analysis (GSCA). Pada
GSCA diperlukan spesifikasi model pengukuran (reflektif atau formatif) dan model struktural. Kedua sub model tersebut diintegrasikan ke dalam sebuah persamaan aljabar, dan diperlukan pendugaan parameter. Pendugaan parameter GSCA memiliki satu kriteria tunggal secara konsisten yaitu meminimumkan residual dari model terintegrasi tersebut. Dengan demikian analisis GSCA memiliki kriteria global optimasi sehingga dapat memberikan kesesuaian model secara global (keseluruhan). Merujuk pada hal tersebut, maka kegunaan GSCA adalah untuk mendapatkan model struktural yang powerfull guna tujuan konfirmasi. Oleh karena itu, metode GSCA adalah setara dengan analisis model struktural berbasis kovarians (SEM). Dengan demikian analisis GSCA juga powerfull untuk menguji model berbasis teori, atau dengan kata lain untuk mengonfirmasi teori tentang hubungan antar variabel yang terdapat di dalam model struktural (Solimun, 2012).

\section{HASIL PENELITIAN DAN PEMBAHASAN}

Analisis data kuantitatif ini mengolah data mentah agar menjelaskan persoalan yang diteliti dengan menggunakan angka statistik memakai bantuan komputer program Generalized Structured Component Analysis (GeSCA) dengan diawali melakukan uji validitas dan reliabilitas instrumennya. Kemudian dilanjutkan uji asumsi linearitas untuk memastikan bahwa hubungan antar variabel memenuhi asumsi linear. Jumlah responden sebanyak 34 dan semuanya diberikan kuesioner untuk dimintakan jawaban atas setiap pertanyaan. Jumlah kuesioner yang kembali sebanyak 31 kuesioner dan layak untuk dilakukan analisis dengan menggunakan GSCA. Sedangkan sisanya sebanyak 3 kuesioner tidak kembali.

Uji validitas terhadap butir pertanyaan dari kuesioner digunakan untuk mengukur instrumen penelitian. Apabila nilai koefisien korelasi $(r) \geq 0,30$ maka instrumen penelitian 
tersebut dinyatakan valid dan sebaliknya. Untuk mengetahui instrumen angket sudah memenuhi kriteria valid maka dapat dilihat pada tabel 1. Hasil perhitungan tersebut menunjukkan semua butir yang telah disusun oleh peneliti menunjukkan nilai $r$ hitung di atas 0,30 dan dinyatakan valid, tetapi ada juga butir yang terdapat nilai di bawah 0,30 yaitu pada butir pertanyaan X125 dan dinyatakan tidak valid. Butir yang tidak valid dikeluarkan dari daftar butir pertanyaan dan kemudian dilakukan uji validitas tahap kedua dan hasilnya dinyatakan valid.

\section{Tabel 1}

\section{Hasil Uji Validitas}

\begin{tabular}{|c|c|c|c|c|c|c|c|c|}
\hline Item & $\mathbf{R}_{\text {Hitung }}$ & Ket & Item & $\mathbf{R}_{\text {Hitung }}$ & Ket & Item & $\mathbf{R}_{\text {Hitung }}$ & Ket \\
\hline X111 & 0,777 & Valid & X151 & 0,771 & Valid & X241 & 0,539 & Valid \\
\hline X112 & 0,841 & Valid & X152 & 0,849 & Valid & X242 & 0,870 & Valid \\
\hline X112 & 0,642 & Valid & X153 & 0,796 & Valid & X243 & 0,924 & Valid \\
\hline X114 & 0,616 & Valid & X154 & 0,910 & Valid & X244 & 0,949 & Valid \\
\hline X115 & 0,622 & Valid & X155 & 0,902 & Valid & X251 & 0,818 & Valid \\
\hline X121 & 0,883 & Valid & X161 & 0,893 & Valid & X252 & 0,943 & Valid \\
\hline X122 & 0,883 & Valid & X162 & 0,903 & Valid & X253 & 0,873 & Valid \\
\hline X123 & 0,758 & Valid & X163 & 0,875 & Valid & X261 & 0,845 & Valid \\
\hline X124 & 0,885 & Valid & X164 & 0,792 & Valid & X262 & 0,759 & Valid \\
\hline X126 & 0,773 & Valid & X165 & 0,907 & Valid & X263 & 0,845 & Valid \\
\hline X127 & 0,803 & Valid & X166 & 0,914 & Valid & Y11 & 0,937 & Valid \\
\hline X131 & 0,672 & Valid & X211 & 0,622 & Valid & Y12 & 0,844 & Valid \\
\hline X132 & 0,600 & Valid & X212 & 0,806 & Valid & Y13 & 0,409 & Valid \\
\hline X133 & 0,858 & Valid & X213 & 0,833 & Valid & Y14 & 0,844 & Valid \\
\hline X134 & 0,923 & Valid & X214 & 0,759 & Valid & Y21 & 0,853 & Valid \\
\hline X135 & 0,839 & Valid & X221 & 0,877 & Valid & Y22 & 0,644 & Valid \\
\hline X136 & 0,810 & Valid & X222 & 0,807 & Valid & Y23 & 0,801 & Valid \\
\hline X137 & 0,800 & Valid & X223 & 0,868 & Valid & Y24 & 0,835 & Valid \\
\hline X141 & 0,773 & Valid & X231 & 0,785 & Valid & & & \\
\hline X142 & 0,872 & Valid & X232 & 0,785 & Valid & & & \\
\hline X143 & 0,627 & Valid & X233 & 0,923 & Valid & & & \\
\hline X144 & 0,603 & Valid & X234 & 0,898 & Valid & & & \\
\hline & & & X235 & 0,882 & Valid & & & \\
\hline
\end{tabular}

Sumber: Data Primer Diolah SPSS

Hasil uji reliabilitas dalam penelitian ini menunjukkan bahwa semua indikator pada variabel QA dan ISO memiliki nilai Cronbach Alpha lebih besar dari nilai batas kemungkinan reliabilitas (rule of thumb), yaitu 0,6. Tetapi pada indikator kinerja terdapat satu indikator yang tidak reliabel karena nilai Cronbach Alpha lebih kecil dari 0,6. Kemudian setelah dicermati pada Cronbach's Alpha if item Deleted ditemukan butir Y13 yang jika dihilangkan maka nilai Cronbach Alpha menjadi di atas 0,6. Setelah diuji kembali dinyatakan reliabel.
Tabel 2

Hasil Uji Linieritas

\begin{tabular}{|c|l|c|c|c|}
\hline \multirow{2}{*}{ No } & \multirow{2}{*}{ Hubungan Antar Variabel } & \multicolumn{3}{|c|}{ Equation Linear } \\
\cline { 3 - 5 } & & $\mathrm{F}$ & $\mathrm{Sig}$ & Hasil \\
\hline 1 & $\begin{array}{l}\text { Quality Assurance (X1) } \\
\rightarrow \text { ISO (X2) }\end{array}$ & 50.007 & 0,000 & Linear \\
\hline 2 & $\begin{array}{l}\text { Quality Assurance (X1) } \\
\rightarrow \text { Kinerja (Y) }\end{array}$ & 13,957 & 0,001 & Linear \\
\hline 3 & ISO (X2) $\rightarrow$ QA (X1) & 50,007 & 0,000 & Linear \\
\hline 4 & ISO (X2) $\rightarrow$ Kinerja (Y) & 11,748 & 0,002 & Linear \\
\hline
\end{tabular}

Sumber: Data primer diolah SPSS

Pada tabel 2 diperoleh nilai equation linear pada hasil pengujian linearitas menjelaskan bahwa model hubungan antara variabel penelitian ini memenuhi asumsi linearitas dengan nilai signifikansi $(p<0,05)$ maka model dapat dinyatakan linear. Setelah lolos dari uji validitas dan reliabilitas serta memenuhi asumsi linearitas maka tahap selanjutnya adalah analisis data dengan menggunakan program Generalized Structured Component Analysis (GSCA) yang dimulai dari analisis Goodness of Fit seperti pada tabel 3.

Tabel 3

Goodness of Fit

\begin{tabular}{|c|c|}
\hline \multicolumn{2}{|c|}{ Model Fit } \\
\hline FIT & 0.736 \\
\hline AFIT & 0.715 \\
\hline GFI & -24.525 \\
\hline SRMR & 0.358 \\
\hline NPAR & 30 \\
\hline
\end{tabular}

Sumber: Hasil Olahan Output GeSCA

Berdasarkan hasil analisis data, nilai FIT menunjukkan varian total dari semua variabel dapat dijelaskan oleh model tertentu. Nilai FIT berkisar dari 0 sampai 1 (Solimun, 2010). Jadi model yang terbentuk dapat menjelaskan semua variabel yang ada sebesar 0,736. Keragaman QA, ISO dan Kinerja dapat dijelaskan oleh model sebesar $73,6 \%$ dan sisanya $26,4 \%$ di jelaskan oleh varian yang lain.

Adjusted dari FIT yang hampir sama dengan nilai FIT, namun karena variabel 
yang mempengaruhi kinerja tidak hanya satu melainkan ada dua variabel sehingga akan lebih baik apabila interpretasi tentang ketepatan model menggunakan FIT yang sudah terkoreksi atau AFIT. Karena semakin banyak variabel yang mempengaruhi maka nilai FIT akan semakin besar karena proporsi keragaman juga akan meningkat sehingga untuk menyesuaikan dengan variabel yang ada dapat menggunakan FIT yang sudah terkoreksi. Jika dilihat nilai AFIT sebesar 0,715 menunjukkan bahwa model dapat dijelaskan sebesar $71,5 \%$ dan sisanya $28,5 \%$ dapat dijelaskan oleh variabel lain.

Nilai GFI (unweighted least Square) dan SRMR (standartdized root mean Square residual) keduanya sebanding dengan perbedaan kovarian sampel dan kovarian yang diproduksi oleh penduga parameter GSCA. Hasil analisis tersebut nilai GFI $=-24,525$ lebih kecil 0,90 maka model tersebut dapat dikatakan kurang sesuai atau kurang baik. Namun nilai SRMR sebesar 0,358> 0,1 dapat dinyatakan model kurang sesuai. Hal ini memungkinkan terjadi pada penelitian ini karena arah indikator pengukuran antara variabel belum diketahui secara pasti dan pengaruh kompleksitas model. Tetapi masih dapat ditolerir karena nilai SRMR mendekati nol (Hu dan Bentler, 1999 dikutip Imam Ghazali, 2008). Nilai NPAR sebesar 30 merupakan jumlah parameter bebas yang termasuk koefisien loading (c), koefisien bobot (w), dan koefisien jalur (b) penelitian ini.

Berdasarkan goodness-of-fit model struktural dan model keseluruhan dengan uji FIT, AFIT, GFI dan SRMR dapat disimpulkan bahwa model yang spesifikasi dalam penelitian ini mampu menjelaskan $71,5 \%$ varian data yang telah terkoreksi. Namun, nilai GFI sebesar -24,525 dan SRMR sebesar 0,358 yang menunjukkan model fit kurang sesuai atau kurang baik.
Tabel 4

Measurement Model Quality Assutrance

\begin{tabular}{|c|c|c|c|c|c|c|c|c|c|}
\hline \multirow{2}{*}{ Variable } & \multicolumn{3}{|c|}{ Loading } & \multicolumn{3}{|c|}{ Weight } & \multicolumn{3}{|c|}{ SMC } \\
\hline & Estimate & SE & CR & Estimate & SE & CR & Estimate & SE & CR \\
\hline QA & & & & $\mathrm{AVE}=0$ & $715, \mathrm{Alpl}$ & $=0.90$ & & & \\
\hline $\mathrm{X} 1.2$ & 0.585 & 0.162 & $3.62^{*}$ & 0.004 & 0.082 & 0.05 & 0.342 & 0.166 & $2.06^{*}$ \\
\hline $\mathrm{X} 1.3$ & 0.922 & 0.093 & $9.93^{*}$ & 0.356 & 0.108 & $3.3^{*}$ & 0.851 & 0.131 & $6.49^{*}$ \\
\hline $\begin{array}{l}\mathrm{X} 1.4 \\
\end{array}$ & 0.779 & \begin{tabular}{|l|}
0.087 \\
\end{tabular} & $8.95^{*}$ & 0.213 & 0.086 & $2.48^{*}$ & 0.606 & 0.141 & $4.3^{*}$ \\
\hline $\mathrm{X1.5}$ & 0.946 & 0.032 & $29.63^{*}$ & 0.450 & 0.106 & $4.24^{*}$ & 0.896 & 0.058 & $15.32^{\circ}$ \\
\hline $\mathrm{X} 1.6$ & 0.939 & 0.032 & $29.18^{*}$ & 0.083 & 0.106 & 0.78 & 0.881 & 0.059 & $14.94^{\circ}$ \\
\hline
\end{tabular}

Sumber: Hasil Olahan Output GeSCA

$\mathrm{CR}^{*}=$ significant at .05 level

Berdasarkan hasil analisis dapat dilihat untuk nilai masing-masing indikator pada setiap variabel. Pertama variabel QA terdapat enam indikator yang mempengaruhi terbentuknya variabel. Namun dalam analisis ini ada satu indikator yaitu X1.1 di keluarkan dari komponen pembentuk variabel QA karena nilainya kurang dari 0,5 pada analisis faktor. Selanjutnya jika dilihat dari nilai loading estimate diperoleh indikator X1.5 (standar sarana dan prasarana) adalah yang paling dapat mendeskripsikan dimensi QA pada program studi. Nilai estimate indikator tersebut paling besar di antara lima indikator yang lain, yaitu sebesar 0.946 . Variabel ISO 9000 terdapat enam indikator yang mempengaruhi terbentuknya variabel. Jika dilihat dari nilai loading estimate diperoleh indikator X2.4 (perbaikan dan pencegahan tindakan) yang paling mampu mendeskripsikan dimensi ISO pada program studi. Nilai estimate indikator tersebut paling besar di antara enam indikator yang lain, yaitu sebesar 0.952 . 
Tabel 5

Measurement Model International Standart Organization

\begin{tabular}{|c|c|c|c|c|c||c|c|c||c||}
\hline \multirow{2}{*}{ Variable } & \multicolumn{3}{|c|}{ Loading } & \multicolumn{3}{c||}{ Weight } & \multicolumn{3}{c||}{ SMC } \\
\cline { 2 - 11 } & Estimate & SE & CR & Estimate & SE & CR & Estimate & SE & CR \\
\hline \multicolumn{10}{|c||}{ AVE $=0.772$, Alpha $=0.943$} \\
\hline ISO & \multicolumn{10}{|c||}{ X2.1 } & 0.791 & 0.061 & $12.87^{*}$ & 0.166 & 0.080 & $2.08^{*}$ & 0.626 & 0.097 & $6.46^{*}$ \\
\hline X2.2 & 0.894 & 0.060 & $14.86^{*}$ & 0.270 & 0.096 & $2.82^{*}$ & 0.798 & 0.100 & $8.0^{*}$ \\
\hline $\mathrm{X} 2.3$ & 0.876 & 0.048 & $18.09^{*}$ & 0.096 & 0.095 & 1.01 & 0.767 & 0.082 & $9.34^{*}$ \\
\hline X2.4 & $\mathbf{0 . 9 5 2}$ & $\mathbf{0 . 0 2 0}$ & $\mathbf{4 7 . 4 6 ^ { * }}$ & 0.454 & 0.161 & $2.82^{*}$ & 0.907 & 0.038 & $24.03^{*}$ \\
\hline \hline $\mathrm{X} 2.5$ & 0.887 & 0.077 & $11.55^{*}$ & 0.120 & 0.093 & 1.29 & 0.787 & 0.118 & $6.69^{*}$ \\
\hline $\mathrm{X} 2.6$ & 0.865 & 0.041 & $21.06^{*}$ & 0.006 & 0.119 & 0.05 & 0.748 & 0.071 & $10.51^{*}$ \\
\hline \hline
\end{tabular}

Sumber: Hasil Olahan Output GeSCA

$\mathrm{CR}^{*}=$ significant at .05 level

Variabel kinerja terdapat dua indikator yang mempengaruhi terbentuknya variabel. Jika dilihat dari nilai loading estimate diperoleh indikator Y1 (peminat program studi) yang paling mampu mendeskripsikan dimensi kinerja program studi. Nilai estimate indikator tersebut paling besar di antara indikator yang lain, yaitu sebesar 0.896 .

Tabel 6

Measurement Model Kinerja

\begin{tabular}{|c|c|c|c|c|c|c|c|c|c|}
\hline Variable & \multicolumn{3}{|c|}{ Loading } & \multicolumn{3}{c|}{ Weight } & \multicolumn{3}{c|}{ SMC } \\
\hline & Estimate & SE & CR & Estimate & SE & CR & Estimate & SE & CR \\
\hline Kinerja & \multicolumn{9}{c|}{ AVE $=0.781$, Alpha $=0.713$} \\
\hline Y1 & $\mathbf{0 . 8 9 6}$ & $\mathbf{0 . 1 1 4}$ & $\mathbf{7 . 8 8}^{*}$ & 0.595 & 0.120 & $4.97^{*}$ & 0.804 & 0.115 & $6.96^{\circ}$ \\
\hline Y2 & 0.871 & 0.071 & $12.23^{*}$ & 0.536 & 0.089 & $6.03^{*}$ & 0.758 & 0.119 & $6.37^{*}$ \\
\hline
\end{tabular}

Sumber: Hasil Olahan Output GeSCA

$\mathrm{CR}^{*}=$ significant at .05 level

Berdasarkan nilai pengukuran model yang diperoleh, indikator X1.5 (standar sarana dan prasarana) memberikan pengaruh signifikan terhadap variabel QA karena nilai titik kritis yang diperoleh sebesar 29,63* signifikan pada tingkat kepercayaan 95\%. Kemudian, pada variabel ISO diperoleh indikator X2.4 (perbaikan dan pencegahan tindakan) adalah yang paling berpengaruh signifikan terhadap variabel ISO nilai titik kritis yang diperoleh sebesar $47,46^{*}$ signifikan pada tingkat kepercayaan 95\%. Selanjutnya variabel Kinerja diperoleh indikator Y1 (peminat program studi) adalah yang paling berpengaruh terhadap variabel Kinerja dengan nilai titik kritis yang diperoleh sebesar 7,88* signifikan pada tingkat kepercayaan $95 \%$.

\section{Tabel 7}

Structural Model

\begin{tabular}{|l|c|c|c|}
\hline \multicolumn{4}{|c|}{ Path Coefficients } \\
\hline & Estimate & SE & CR \\
\hline QA->ISO & 0.884 & 0.039 & $22.44^{*}$ \\
\hline QA->Kinerja & 0.802 & 0.663 & 1.21 \\
\hline ISO->QA & 0.884 & 0.039 & $22.44^{*}$ \\
\hline ISO->Kinerja & -0.159 & 0.641 & 0.25 \\
\hline
\end{tabular}

Sumber: Hasil Olahan Output GeSCA

$\mathrm{CR}^{*}=$ significant at .05 level

Nilai estimate pada jalur QA ke ISO dan jalur ISO ke QA memiliki nilai estimate yang sama besar yaitu 0,884 dan signifikan pada tingkat kepercayaan 95\%. Artinya bahwa jalur QA ke ISO maupun jalur ISO ke QA signifikan berlaku umum. Selanjutnya untuk jalur QA ke kinerja memiliki nilai estimate sebesar 0,802. Tetapi tidak signifikan pada tingkat kepercayaan $95 \%$. Artinya bahwa variabel QA mampu menjelaskan kinerja sebesar 0,802 tetapi tidak berlaku umum dan hanya berlaku pada kasus kinerja program studi pada perguruan tinggi tersebut. Sedangkan untuk jalur ISO ke kinerja memiliki nilai estimate sebesar -0,159 dan tidak signifikan pada tingkat kepercayaan $95 \%$. Artinya bahwa ISO memiliki hubungan negatif sebesar 0,159, dan tidak berlaku umum dan hanya berlaku pada kasus kinerja program studi tersebut. 

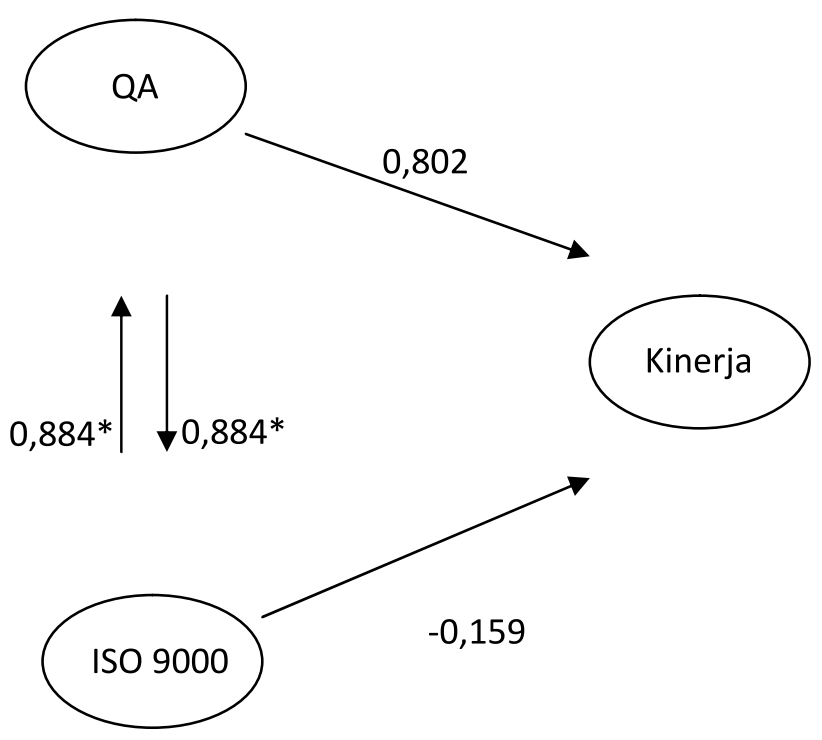

Gambar 1

Structural Model

\section{QA $\rightarrow$ Kinerja}

Berdasarkan hasil analisis di atas, QA memiliki hubungan positif terhadap kinerja dan tidak signifikan terhadap kinerja program studi pada perguruan tinggi swasta tersebut karena nilai kritis yang diperoleh tidak signifikan pada tingkat kepercayaan 95\%. Artinya bahwa QA mampu menjelaskan kinerja program studi. Tetapi tidak berlaku umum dan hanya berlaku pada kasus kinerja program studi yang bersangkutan. Kondisi ini sangat menarik untuk dibahas karena secara teori, variabel QA akan mampu menjelaskan dan berpengaruh terhadap kinerja tetapi pada kondisi pengukuran variabel QA terhadap kinerja program studi pada perguruan tinggi swasta tersebut tidak terbukti. Kalau melihat mulai penerapan QA pada perguruan tinggi swasta tersebut memang relatif belum lama. Sehingga budaya penjaminan mutu belum meningkatkan kesadaran dan belum mampu membentuk perilaku dan budaya para staf pengajar maupun staf administrasi. Disamping itu, pada perguruan tinggi ter- sebut juga masih ada beberapa program studi yang relatif baru berdiri. Sehingga komitmen untuk menerapkan konsep penjaminan mutu masih dalam proses adaptasi. Hasil penelitian ini menjadi masukan sekaligus sebagai informasi bagi pimpinan atau kepada biro yang bersangkutan untuk lebih giat untuk menginformasikan dan mensosialisasikan konsep penjaminan mutu kepada seluruh staf sehingga ada perubahan ke arah perilaku penjaminan mutu.

\section{ISO $\rightarrow$ Kinerja}

Berdasarkan hasil analisis di atas, ISO memiliki hubungan negatif terhadap kinerja dan tidak signifikan terhadap kinerja program studi karena nilai kritis yang diperoleh tidak signifikan pada tingkat kepercayaan 95\%. Kondisi ini sangat menarik untuk dibahas karena secara teori variabel ISO akan berpengaruh terhadap kinerja tetapi dalam kasus ini ISO berpengaruh negatif pada kinerja program studi tersebut. Selain itu ISO memiliki nilai yang tidak signifikan yang berarti bahwa kondisi ini tidak berlaku umum dan hanya berlaku pada kasus khusus yaitu kinerja program studi tersebut. Variabel ISO memang sudah memuat standar-standar yang harus dikerjakan oleh seluruh staf. Mungkin karena tuntutan administrasi sehingga secara fisik bisa dilakukan oleh seluruh staf hanya sekedar untuk memenuhi audit internal maupun eksternal. Hal ini terlihat indikator yang paling mampu menjelaskan variabel ISO adalah indikator perbaikan dan pencegahan tindakan. Dapat dibayangkan apabila tidak ada audit internal dan eksternal, maka perilaku dan budaya untuk memenuhi standar-standar yang ada dalam ISO tidak akan terlaksana dengan baik. Ini menjadi tugas pimpinan untuk memberikan tauladan yang baik terhadap seluruh bawahannya untuk peningkatan kualitas pendidikan tinggi ke depan. 


\section{QA $\rightarrow$ ISO}

Berdasarkan hasil analisis di atas, QA memiliki hubungan positif terhadap ISO dan QA mampu mempengaruhi secara signifikan terhadap ISO karena nilai kritis yang diperoleh signifikan pada tingkat kepercayaan 95\%. Hal ini sudah sesuai dengan teori bahwa implementasi QA di program studi mampu mempengaruhi praktek ISO 9000 pada program studi. Hal ini sangat menarik karena pengaruh QA terhadap ISO berlaku umum. Artinya bahwa semua organisasi khususnya program studi pada suatu pendidikan tinggi akan mendapatkan hasil yang sama, bahwa QA terbukti mempengaruhi praktek ISO 9000 .

\section{ISO $\rightarrow$ QA}

Berdasarkan hasil analisis di atas, ISO memiliki hubungan positif terhadap QA dan ISO mampu mempengaruhi secara signifikan terhadap QA karena nilai kritis yang diperoleh signifikan pada tingkat kepercayaan 95\%. Hal ini sudah sesuai dengan teori bahwa implementasi ISO di program studi mampu mempengaruhi QA pada program studi. Hal ini sangat menarik karena pengaruh ISO terhadap QA berlaku umum. Artinya bahwa semua organisasi khususnya program studi pada perguruan tinggi akan mendapatkan hasil yang sama, bahwa ISO terbukti mempengaruhi praktek QA.

\section{KESIMPULAN DAN SARAN}

\section{Kesimpulan}

1. Berdasarkan hasil analisis data, nilai FIT menunjukkan varian total dari semua variabel dapat dijelaskan oleh model tertentu. Nilai FIT berkisar dari 0 sampai 1. Jadi model yang terbentuk dapat menjelaskan semua variabel yang ada sebesar 0,736. Keragaman QA, ISO dan Kinerja dapat dijelaskan oleh model sebesar $73,6 \%$ dan sisanya $(26,4 \%)$ dapat dijelaskan oleh variabel yang lain. Berarti model tersebut baik untuk menjelaskan fenomena yang dikaji.

2. Berdasarkan hasil analisis dapat dilihat nilai masing-masing indikator setiap variabel. Pertama variabel QA terdapat lima indikator yang mempengaruhi terbentuknya variabel. Jika dilihat dari nilai loading estimate yang diperoleh masing-masing indikator, indikator standar sarana dan prasarana adalah yang paling dapat mendeskripsikan dimensi QA. Nilai estimate indikator tersebut paling besar diantara indikator yang lain, yaitu sebesar 0.946.

3. Variabel ISO juga terdapat enam indikator yang mempengaruhi terbentuknya variabel. Jika dilihat dari nilai loading estimate yang diperoleh masing-masing indikator, maka indikator perbaikan dan pencegahan tindakan adalah yang paling dapat mendeskripsikan dimensi ISO. Nilai estimate indikator tersebut paling besar diantara indikator yang lain, yaitu sebesar 0.952 .

4. Variabel Kinerja terdapat dua indikator yang mempengaruhi terbentuknya variabel. Jika dilihat dari nilai loading estimate yang diperoleh masing-masing indikator, pada indikator peminat program studi adalah yang paling dapat mendeskripsikan variabel Kinerja. Nilai estimate indikator tersebut paling besar di antara indikator yang lain, yaitu sebesar 0.896 .

5. Berdasarkan hasil analisis di atas, QAmemiliki hubungan positif terhadap kinerja tetapi tidak signifikan terhadap kinerja program studi karena nilai kritis yang diperoleh tidak signifikan pada tingkat kepercayaan 95\%. Sehingga QA tidak mempengaruhi kinerja program studi pada perguruan tinggi swasta tersebut.

6. Berdasarkan hasil analisis di atas, ISO memiliki hubungan negatif terhadap kinerja 
dan tidak signifikan terhadap kinerja program studi karena nilai kritis yang diperoleh tidak signifikan pada tingkat kepercayaan 95\%. Sehingga ISO tidak berlaku umum dan hanya berlaku khusus untuk kinerja program studi tersebut.

7. Berdasarkan analisis di atas, variabel QA dan ISO atau sebaliknya memiliki hubungan positif dan mampu mempengaruhi ke masingmasing variabel secara umum karena nilai kritis yang diperoleh signifikan pada tingkat kepercayaan $95 \%$.

\section{Saran}

Saran dalam penelitian ini adalah sebagai berikut:

1. Karena variabel ISO terbukti memiliki hubungan negatif dan tidak signifikan, maka hal ini menjadi perhatian yang sangat serius bagi pihak pimpinan atau biro yang terkait untuk memberikan pemahaman dan pencerahan terhadap implementasi ISO 9000 sehingga akan membentuk perilaku dan akan mengarah pada budaya untuk meningkatkan kinerja program studi.

2. Variabel QA terbukti tidak signifikan terhadap kinerja, maka hal ini menjadi perhatian serius bagi pimpinan untuk mensosialisasikan dan mengarahkan kepada seluruh staf pengajar atau staf administrasi secara serius dalam mengimplementasikan QA di lembaga tersebut.

\section{DAFTAR PUSTAKA}

Anderson, S. W., Daly, J. D. dan M. F. Johnson. 1999. "Why firms seek ISO 9000 certification: Regulatory compliance or competitive advantage?", Production and Operations Management, 8 (1), 2843
Brecka, J. 1994. "Study finds gains with ISO 9000 registration increase over time", Quality Progress, 27 (5), 18-20

Chow-Chua, C. M., Goh, M. dan T. B. Wan. 2003. "Does ISO 9000 certification improve business performance?", International Journal of Quality and Reliability Management, 20 (8), 936-953

Corbett, C. J., Montes, M. J., Kirsch, D. A. dan M. J. Alvarez-Gil. 2002. "Does ISO 9000 Certification Pay?", ISO Management Systems. July-August, 31-40.

Corbett, C. J., Montes-Sancho, M. J. dan D. A. Kirsch. 2005. "The financial impact of ISO 9000 certification in the United States: an empirical analysis", Management Science 51 (7), 1046- 1059

Dirjen Dikti, 2008. Sistem Penjaminan Mutu Perguruan Tinggi. Departemen Pendidikan Nasional, Direktorat Jenderal Pendidikan Tinggi.

Douglas, A., Coleman, S. dan R. Oddy. 2003. "The case for ISO9000", The TQM Magazine, 15 (5), 316-324

Ebrahimpour, M., Withers, B. dan N. Hikmet. 1997. "Experiences of U.S. and foreign owned firms: A new perspective on ISO 9000 implementation", International Journal of Production Research. 35 (2), 569-576

Gaspersz, Vincent. 2011. Total Quality Management. Vinchristo Publication. Bogor.

Han, S. Bruce, Shaw K. Chen, dan M. Ebrahimpour. 2007. "The Impact of ISO 9000 on TQM and Business Performance", Journal of Business and Economic Studies, 13 (2).

Jabnoun, Naceur. 2002. "Control processes for total quality management and quality assurance", Work Study, 51 (4), 182-190

Mann, R. dan D. Kehoe. 1994. "An evaluation of the effects of quality improvement 
activities on business performance", International Journal of Quality and Reliability Management, 11 (4), 29-44

Porter, L. J. dan S. J. Tanner. 1996. Assessing Business Excellence. ButterworthHeinemann.

Singgih Moses L dan Rahmayanti. 2008. FaktorFaktor Yang Mempengaruhi Kualitas Pendidikan Pada Perguruan Tinggi. Prosiding Seminar Nasional Teknoin. Bidang Teknik Industri

Solimun. 2010. Analisis Multivariat Pemodelan Struktural: Metode Partial Least Square. CV Citra: Malang
Solimun.2012.Pemodelan StrukturalGeneralized Structured Component Analysis GSCA. Program Studi Statistika. Universitas Brawijaya. Malang

Terziovski, M., Samson, D. dan D. Dow. 1997. "The Business value of quality management systems certification evidence from Australia and New Zealand", Journal of Operations Management, 15, 1-18

Yeung, A. C. L., Lee, T. S. dan L. Y. Chan. 2003. "Senior management perspectives and ISO 9000 effectiveness: an empirical research", International Journal of Production Research. 41, 545-569

Yorke, M. 1997. "This way QA? Quality Assurance in education", 5 (2), 97 - 100 